Article

\title{
Impact of the Emission Control of Diesel Vehicles on Black Carbon (BC) Concentrations over China
}

\author{
Jiamao Zhou ${ }^{1}$, Xuexi Tie ${ }^{1,2,3, *}$, Yunbo Yu ${ }^{4,5}$, Shuyu Zhao ${ }^{1}$, Guohui Li ${ }^{1}$, Suixin Liu ${ }^{1}$, \\ Ting Zhang ${ }^{1}$ and Wenting Dai ${ }^{1}$ \\ 1 Institute of Earth Environment, Key Laboratory of Aerosol Chemistry and Physics, SKLLQG, \\ Chinese Academy of Sciences, Xi'an 710061, China; zjm@ieecas.cn (J.Z.); zhaosy@ieecas.cn (S.Z.); \\ ligh@ieecas.cn (G.L.); lsx@ieecas.cn (S.L.); zhangting@ieecas.cn (T.Z.); daiwt@ieecas.cn (W.D.) \\ 2 Institute of Urban Environment, Center for Excellence in Regional Atmospheric Environment, \\ Chinese Academy of Sciences, Xiamen 361021, China \\ 3 Shanghai Key Laboratory of Meteorology and Health, Shanghai 200030, China \\ 4 State Key Joint Laboratory of Environment Simulation and Pollution Control, Research Center for \\ Eco-Environmental Sciences, Chinese Academy of Sciences, Beijing 100085, China; ybyu@rcees.ac.cn \\ 5 University of Chinese Academy of Sciences, Beijing 100049, China \\ * Correspondence: tiexx@ieecas.cn
}

Received: 18 April 2020; Accepted: 28 June 2020; Published: 30 June 2020

\begin{abstract}
In order to reduce black carbon (BC) emissions from diesel vehicles, a regional atmospheric chemistry model (WRF-Chem) was used to investigate the effects of installing a high-efficiency device for vehicle exhaust control, a diesel particulate filter (DPF), on diesel vehicles in China. To reduce the uncertainty of estimation, three sensitivity experiments were designed and conducted for different emission scenarios. The first experiment uses the standard black carbon emissions of diesel vehicles without engaging in any emission control actions (referred to as CTRL), and the other two experiments were conducted using different DPF devices to reduce BC emissions by $65 \%$ (CASE1) and 39\% (CASE2), respectively. The results show that the model simulation reasonably represents the measured $\mathrm{BC}$ concentrations. The highest $\mathrm{BC}$ concentrations occurred in large cities of the North China Plain (NCP) and present important seasonal variations. The results suggest that the reduction in diesel vehicle emissions has great benefits for reducing $B C$ pollution not only in winter but also in other seasons. Sensitivity studies show that in CASE1, the average BC concentrations decreased about $\sim 6 \%$ in January and by more than $10 \%$ in the other seasons. The greatest reduction exceeded $50 \%$. In CASE2, the average BC concentrations decreased by about $3.5 \%$ in January and by more than $7 \%$ in the other seasons. This study suggests that adding DPF to a diesel vehicle can have a significant influence on reducing BC concentrations in China. Thus, this study provides a practical basis by which diesel vehicle emissions can be reduced.
\end{abstract}

Keywords: black carbon reduction; diesel vehicles; WRF-Chem model

\section{Introduction}

Black carbon (BC) is the most light-absorbing aerosol that is formed due to the inefficient burning of fossil fuels, biofuels, and biomass, and can strongly absorb visible light, representing the second-most important positive radiative influence of global change after $\mathrm{CO}_{2}$ greenhouse gases [1]. Despite its short residence time in the atmosphere, black carbon affects the solar radiation budget, exerting a significant influence on the climate as a driver of global warming [2,3].

The main sources of $\mathrm{BC}$ emissions include industrial activities, vehicles, biomass burning, and residential burning [4-6]. Mobile sources account for $\sim 25 \%$ of BC emissions, among which $\sim 70 \%$ 
correspond to diesel fuel combustion [4]. The rapid growth of diesel vehicles in mainland China has placed great pressure on the pollution control of fine particles.

Diesel engines use an air-fuel mixture for combustion with higher thermal efficiency than gasoline alone, making diesel more economical and reliable. Diesel is, therefore, widely used in commercial vehicles. The diesel vehicles found in China generally have the characteristics of a high frequency of use, long life, and high mileage which contains higher amount of Particulate Matter (PM) that could cause severe environmental problems. Compared to developed countries, the diesel engine control technology in China is lagging behind. Therefore, levels of pollutant exhaust remain very high, resulting in the higher emissions of diesel vehicles in China. According to the statistics of the "China Vehicle Environmental Management Annual Report" released by the Ministry of Ecology and Environmental of the People's Republic of China (https://www.vecc-mep.org.cn/jdcwrfznb/1870.jhtml), diesel vehicles and diesel-type vehicles have steadily increased in prevalence. The growth rate of China's diesel fuel consumption was $1.24 \%$ in 2017, producing 167 million tons of consumed diesel fuel, while the growth rate of Chinese gasoline fuel consumption decreased in 2017.

The emission control of the black carbon from diesel vehicles is beneficial to air quality, human health, and climate change. There are three ways to decrease the BC emissions of diesel vehicles. One is to improve the standard and quality of diesel fuel, the second is to use purification technologies for diesel engines, and the third is to adopt diesel vehicle exhaust purification devices. A diesel particle filter (DPF) is a typical example of control technology for on-road diesel vehicles which can greatly reduce BC emissions. Its purification efficiency can be as high as $80 \%$ [7,8]. Meanwhile, the DPF method can be easily installed without engine improvement and is widely used throughout the world $[9,10]$. As a very polluted region of eastern China, improving air quality is a very important issue. However, there is almost no detailed estimation of the effects of installing DPF on the changes in BC concentrations due to the reductions in the emissions of diesel vehicles, which become the focus of this study. To better understand the pollution caused by diesel vehicle emissions, it is necessary to carry out emission reduction measures and evaluate the potential benefits of BC pollution control by installing DPF devices.

The purpose of this study is to use a regional dynamical/chemical model (WRF-Chem, The weather research and forecasting model coupled with a chemistry model) to estimate the effects of DPF on BC concentrations in mainland China. First, the model calculation is evaluated by comparison with the measured $\mathrm{BC}$ concentrations, including their spatial distribution and seasonal variations. Second, model sensitivity studies were conducted to investigate how different DPF methods reduce the BC concentrations in mainland China.

\section{Model and Observation Details}

\subsection{WRF-Chem Model Configuration}

WRF-Chem is a regional atmospheric transport model that simultaneously simulates gases, aerosols, and meteorological fields [11]. Simulations were performed using the WRF-Chem version 3.5.1 online, with the domain covering the entire mainland China. Evaluation of the performance was conducted according to procedures documented in numerous previous studies [12-14].

The model domain is centered at $37^{\circ} \mathrm{N}, 102^{\circ} \mathrm{E}$, with $140 \times 120$ grid points at $36 \mathrm{~km}$ horizontal resolution, as shown in Figure 1. Table 1 details the model configurations for this study. This study employed the Regional Acid Deposition Model (RADM2) [15] and The Modal Aerosol Dynamics Model for Europe (MADE) [16] with the Secondary Organic Aerosol Model (SORGAM) [17] chemical schemes. The rapid radiative transfer model for the General Circulation Models (RRTMG) scheme for longwaves (LWs) and shortwaves (SWs), including aerosol direct radiative feedback, was used for radiation calculations [18]. The Morrison double moment cloud microphysics scheme was utilized to include indirect aerosol effects [19]. Dry and wet scavenging and cloud chemistry options were also included. The data for land use, terrain height, soil properties, vegetation fraction, etc., were interpolated from 
the United States Geological Survey (USGS) data and incorporated into the model domain using the WRF pre-processing system.

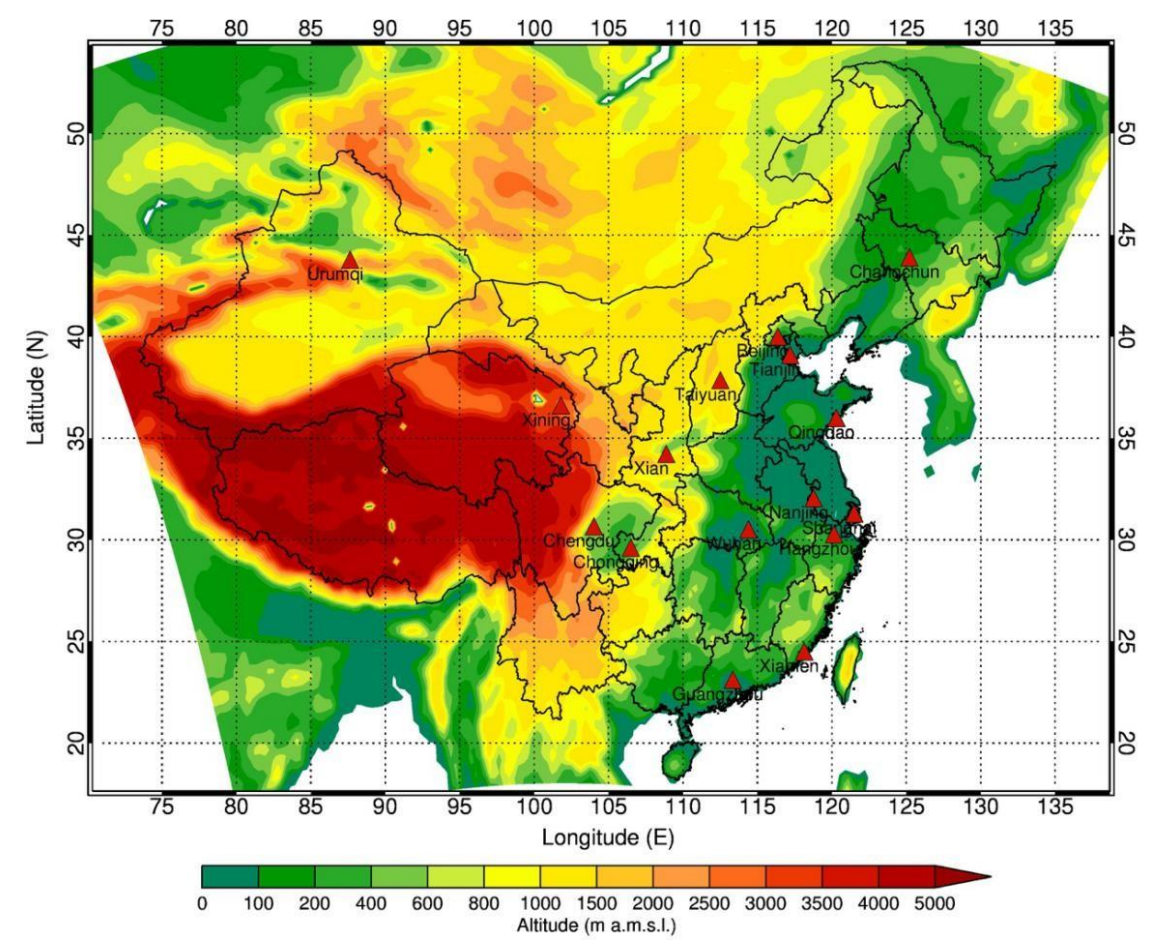

Figure 1. The numerical simulation domain of regional atmospheric chemistry model (WRF-Chem), with the topography and field observation sites of black carbon (BC—red triangles).

Table 1. Regional atmospheric chemistry model (WRF-Chem) schemes and parameterizations used in this study.

\begin{tabular}{cc}
\hline Model Parameter & Description \\
\hline Number of grid points & $140 \times 120$ (horizontal) $\times 35$ (vertical) \\
Horizontal grid projection & Lambert \\
Horizontal resolution & $36 \mathrm{~km} \times 36 \mathrm{~km}$ \\
Model top & $50 \mathrm{hPa}$ \\
Model domain center & $37^{\circ} \mathrm{N}, 102^{\circ} \mathrm{E}$ \\
Chemical mechanisms & RADM2 [15]/ MADE-SORGAM [16,17] \\
Meteorological initial and & National Centers for Environmental Prediction, NCEP $1^{\circ} \times 1^{\circ}$ \\
boundary conditions & reanalysis data http://rda.ucar.edu/datasets $/ \mathrm{ds083.2/}$ \\
SW and LW radiation & RRTMG [18] \\
Cloud Microphysics & Morrison double moment [19] \\
Lateral BC boundary condition & MOZART4 6-h output [20] \\
Land surface model & NOAH [21] \\
Planetary boundary layer & YSU scheme [22] \\
Cumulus parameterization & Grell-3d [23]
\end{tabular}

Note: Regional Acid Deposition Model (RADM2); The Modal Aerosol Dynamics Model for Europe (MADE) with the Secondary Organic Aerosol Model (SORGAM); General Circulation Models (RRTMG).

\subsection{Diesel Vehicles Emission Data}

The basic anthropogenic emissions of gases and aerosol particles were obtained from the Multi-resolution Emission Inventory for China (MEIC) for the year 2010 [24,25] (http://www.meicmodel. org). Five types of emission sources-industry, power plants, transportation, agriculture, and residential sources-are aggregated at a $0.25^{\circ} \times 0.25^{\circ}$ spatial resolution and monthly temporal resolution. Several important emission factors (such as temperature, humidity, altitude, automobile routine parameters, 
and combined meteorology, road network conditions, and traffic flow data) were taken into account for the BC emissions of the transportation sector in MEIC [24,26]. County-level traffic emissions were calculated by the registered vehicle amounts, vehicle types, and county-level emission factors and allocated to grids according to the Chinese roadmap for 2010, which has great advantages for describing the spatial distribution characteristics of automobiles [26].

Black carbon emissions from diesel vehicles in 2017 were estimated and updated using the statistical data reported from China Vehicle Environmental Management Annual Report released by the Ministry of Environmental Protection of the People's Republic of China (https://www.vecc-mep.org. cn/jdcwrfznb/1870.jhtml). According to the China Vehicle Environmental Management Annual Report in 2014 and 2018, the annual $\mathrm{PM}_{2.5}$ emissions of diesel vehicles in 2013 and 2017 were respectively 567,000 and 488,000 $\mathrm{T} \mathrm{y}^{-1}$, corresponding to 19.11 and 19.57 million diesel vehicles. The particulate matter emission ratio of diesel vehicles from 2017 to 2013 was 0.861 . Although China has implemented stringent emission standards and accelerated the elimination of yellow-label vehicles since 2013, the particulate matter from diesel vehicles has not clearly been reduced. The black carbon emissions of diesel vehicles in 2017 were calculated using data from the research conducted by Wang et al. [27]. Wang et al. [27] investigated and analyzed the black carbon emissions from diesel vehicles in 2013. Their results show that the black carbon emissions from diesel vehicles in 2013 were $313,300 \mathrm{~T} \mathrm{y}^{-1}$. The spatial distribution of the emissions in each province of China are summarized in Figure 2. From this figure, it can be seen that the provinces of Henan, Hebei, and Shandong are the top three contributors of black carbon emissions, respectively accounting for $8.8 \%, 8.5 \%$, and $7.7 \%$ of the total emissions in China. Based on the above information, assuming that the black carbon emission factor in 2017 is the same as that in 2013, the diesel vehicle emissions in 2017 were $269,751 \mathrm{~T} \mathrm{y}^{-1}$, which represents a slight decline compared to the 2013 value, as with the PM emission variation trend (using a PM decline ratio of 0.861 for calculations). We updated this value in the transportation emission inventory with provincial contributions in mainland China, as shown in Figure 2.

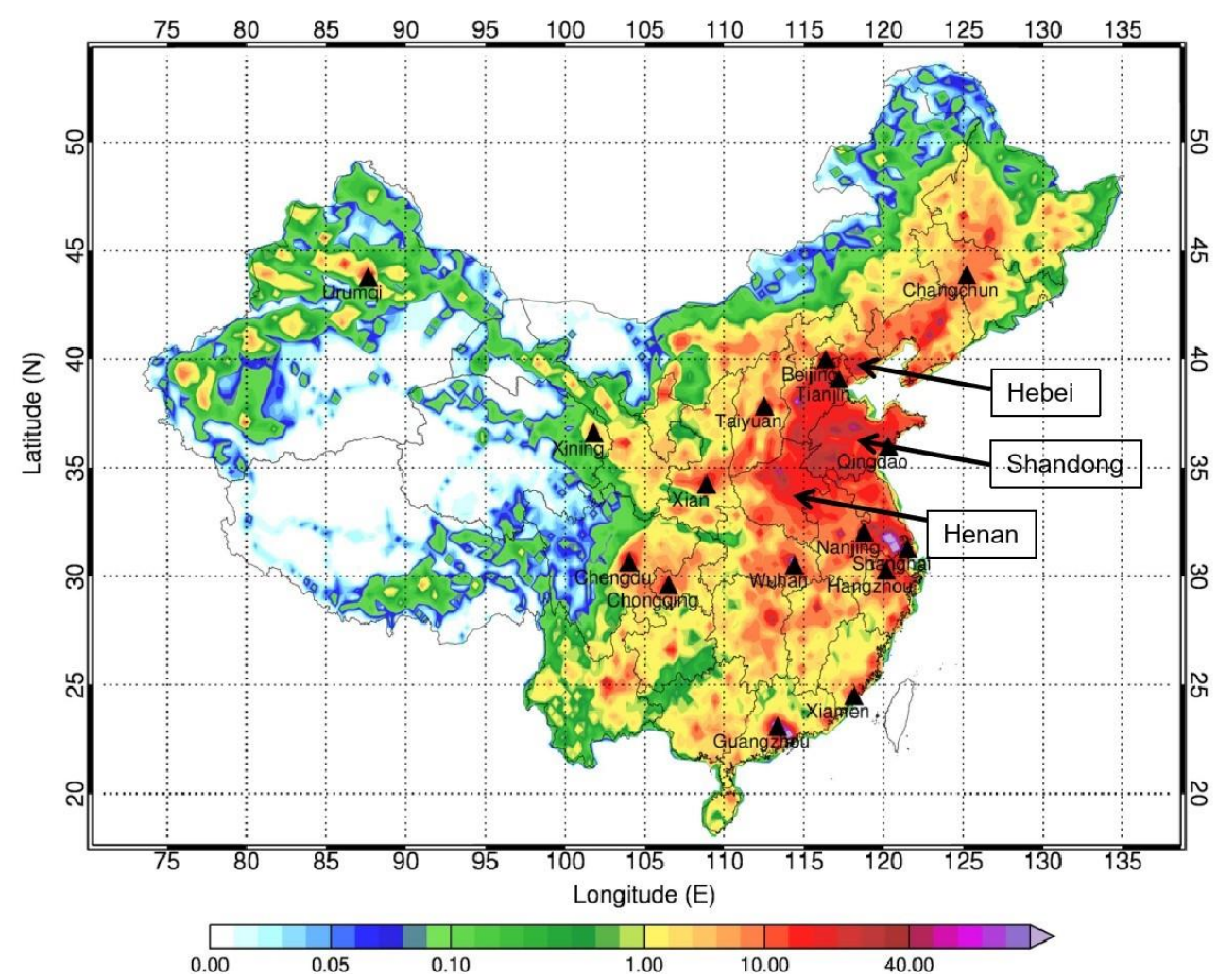

Figure 2. Monthly black carbon emissions of diesel vehicles in the model grids (tons) in mainland China. 


\subsection{Numerical Experiments}

Three sets of experiments for different DPF application scenarios were conducted to investigate the impact on black carbon pollution by applying the BC emission control of diesel vehicles in China. The simulation results for January, April, July, and October in 2017 were analyzed to determine the annual variations that are characteristic of $\mathrm{BC}$.

The first experiment used the standard black carbon emissions of diesel vehicles without any emission control actions (referred to as CTRL), while the other two experiments were conducted using DPF to reduce the BC emissions of different vehicles. According to the China Vehicle Environmental Management Annual Report in 2018 (http://www.vecc-mep.org.cn/180601/1-1P601164953.pdf), the Chinese National Standard particle emissions from diesel vehicles are classified using the following standards, with the percent of total vehicles indicated: China II (16.4\%), China III (64.5\%), China IV $(16.2 \%)$, and China V (2.5\%). China II includes yellow-label cars, which will be forcibly eliminated in the next few years and are thus not discussed in this study. Our experiments therefore focus on China III and China IV diesel vehicles, which comprise the majority of diesel vehicles $(\sim 81 \%)$ in China.

The second and third experiments were sensitivity studies to determine the reduction in $\mathrm{BC}$ emissions from diesel vehicles using advanced devices, such as DPF, which is attached to the exhaust systems of diesel vehicles. The DPF technology currently available utilizes a wall-flow filter positioned in the exhaust system. As the exhaust gases pass through this filter, the emissions of particulate matter are trapped in the filter resulting in the reduction in emissions. These sensitivity studies are compared with the base study (CASE1) to better understand the impacts of improved BC emissions on BC pollution in China.

The second experiment examines the effects of replacing the emissions from China III and China IV diesel vehicles with the emissions from China V diesel vehicles with the help of DPF. As a result, the $\mathrm{BC}$ emissions are reduced by $175,338 \mathrm{~T} \mathrm{y}^{-1}$ (an 80\% reduction). This emission reduction scenario is defined as CASE2.

Since 2018, China III diesel vehicles have been gradually discarded to reduce the BC emissions in China. The third experiment considers a scenario where half of China III vehicles are not eliminated, and all China IV diesel vehicles are replaced by China V diesel vehicles. As a result, the BC emissions from diesel vehicles are reduced by 105,202 $\mathrm{T} \mathrm{y}^{-1}$ (a 39\% reduction). This emission reduction scenario is defined as CASE2.

\subsection{BC Measurements}

In this study, we used a set of BC observations over mainland China from 5-25 January in 2013 to evaluate the calculated BC from the WRF-Chem model. As shown in Figure 1, the observation sites (red triangles) are located in 16 cities across China, including Changchun, Beijing, Tianjin, Xi'an, Xining, Taiyuan, Shanghai, Hangzhou, Xiamen, Wuhan, Chongqing, Chengdu, Nanjing, Guangzhou, and Qingdao. The measurements used Urumqi $47 \mathrm{~mm}$ Whatman QM-A quartz fiber filters, which were sampled every $24 \mathrm{~h}$ by mini-volume air samplers (Airmetrics, Eugene, OR, USA) at $5 \mathrm{~L} \mathrm{~min}^{-1}$ flow rate. The BC concentration was analyzed by using a DRI model 2001 carbon analyzer (Atmoslytic, Inc., Calabasas, CA, USA) with the IMPROVE thermal/optical reflectance (TOR) protocol [28,29]. BC is defined as the sum of three elemental carbon (EC) fractions (EC1, EC2, and EC3 in a $2 \%$ oxygen/98\% helium atmosphere at 580,740 , and $840{ }^{\circ} \mathrm{C}$ ) minus $\mathrm{OP}$ (pyrolyzed carbon) produced at $<580{ }^{\circ} \mathrm{C}$ in an inert atmosphere). Further analysis details and the quality assurance and the quality control can be found in previous studies [30,31].

\section{Results and Discussions}

\subsection{Model Validation}

In order to evaluate the ability of WRF-Chem to simulate the spatial distribution of atmospheric black carbon aerosol in mainland China, this study used the black carbon data collected simultaneously 
in 16 cities in China during 5-25 January 2013 for comparative verification. Figure 3 shows the spatial distribution of the black carbon simulated by WRF-Chem compared to the observed black carbon in the 16 Chinese cities (indicated by triangles). As the figure indicates, the model generally reproduced the spatial variations of black carbon in mainland China. For example, the highest observed and simulated black carbon concentrations appeared in the North China Plain (NCP), with the highest concentration found in the city of Taiyuan. The observed and simulated BC concentrations were 17.0 and $18.6 \mu \mathrm{g} \cdot \mathrm{m}^{-3}$, respectively. The other regions with high BC concentrations were Sichuan Basin, Central China, Northeast China, and the Yangtze River Delta. The major contribution to the BC concentrations is from the solid fuel combustions (such as coal burnings) to the BC concentration in China [32], which is the main cause for the calculated discrepancies of the BC concentrations.

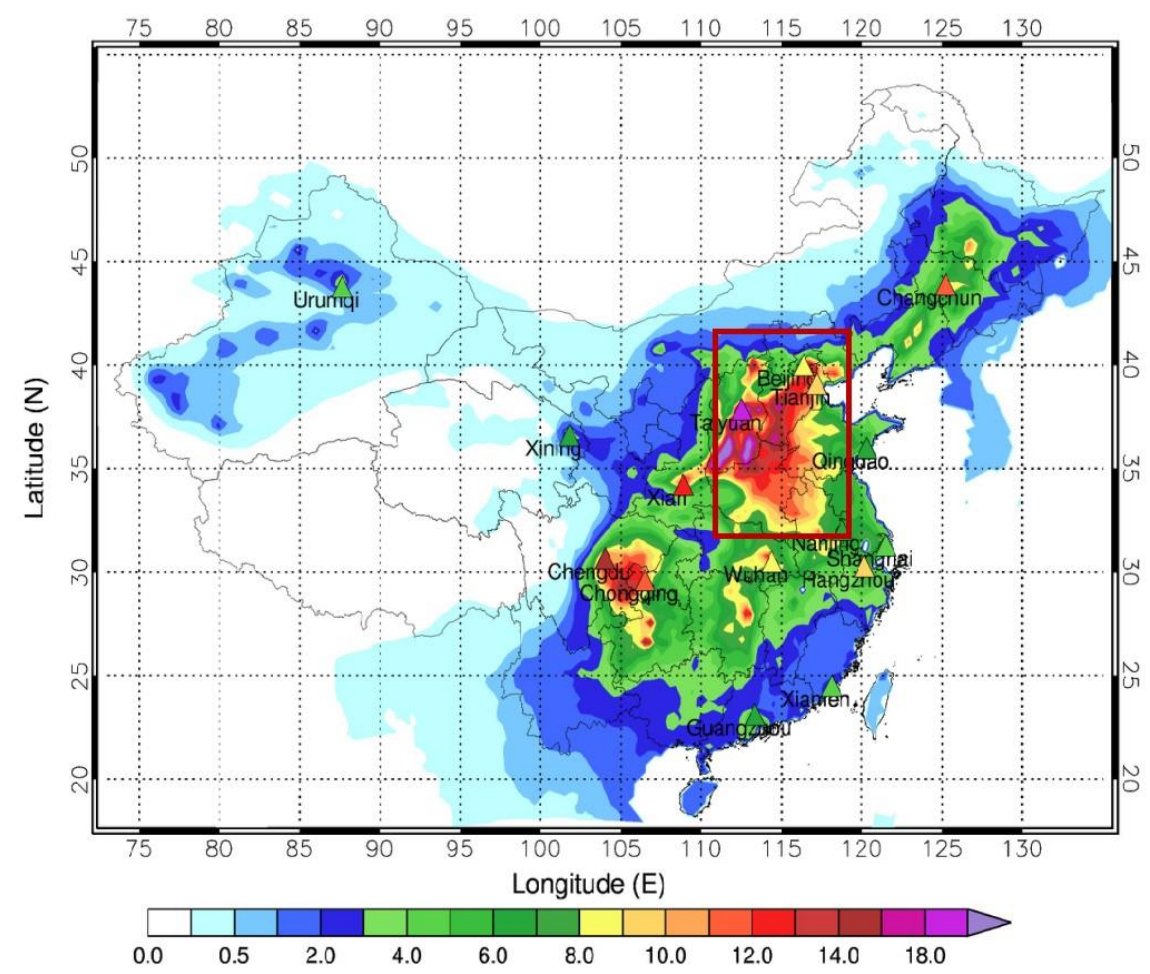

Figure 3. Comparison of WRF-Chem simulated and observed black carbon concentrations $\left(\mu \mathrm{g} \cdot \mathrm{m}^{-3}\right)$ in mainland China averaged for January 2013. Triangles are the sampling sites of 16 cities. The red box represents the North China Plain.

The spatial distribution characteristics indicate that black carbon pollution is closely related to human activities. The mean values of black carbon concentrations in Beijing, Urumqi, Sichuan Basin, Guangzhou, and the Northeast for the simulation were relatively similar to the observed values, with a relative deviation of $\sim 10 \%$. The simulated values for Xining, the southeast coast (Guangzhou, Xiamen), and Taiyuan were underestimated, and in Qingdao, Central China, and the Yangtze River Delta (Shanghai, Nanjing, etc.), the simulated values were overestimated. The reasons for the overestimation or underestimation of black carbon concentration were due to several factors, such as the inaccuracy of the emissions inventory and the differences in meteorological parameters (such as wind speed, wind direction, and precipitation) between the model simulations and observations. In addition, the grid value of this study was $36 \mathrm{~km} \times 36 \mathrm{~km}$. While the simulation data represent the average level within the grid point, the observation data employ single-point sampling, leading to inaccuracies in representing the observed results.

To more clearly show any differences between the model results and observed values, the time series of simulated and observed black carbon concentrations in the large/mega cities in the NCP region (Beijing, Tianjin, and Taiyuan) were compared (as shown in Figure 4). The overall temporal variation 
in Beijing, Tianjin, and Taiyuan is very similar. For the average value, the observed and simulated black carbon concentrations were respectively 8.4 and $8.6 \mu \mathrm{g} \cdot \mathrm{m}^{-3}$ in Beijing, 9.1 and $10.5 \mu \mathrm{g} \cdot \mathrm{m}^{-3}$ in Tianjin, and 18.6 and $17.0 \mu \mathrm{g} \cdot \mathrm{m}^{-3}$ in Taiyuan. The average differences (in the period 5-25 January 2015) between the simulated and observed BC concentrations were $2 \%, 15 \%$, and $-9 \%$ in Beijing, Tianjin, and Taiyuan, respectively.

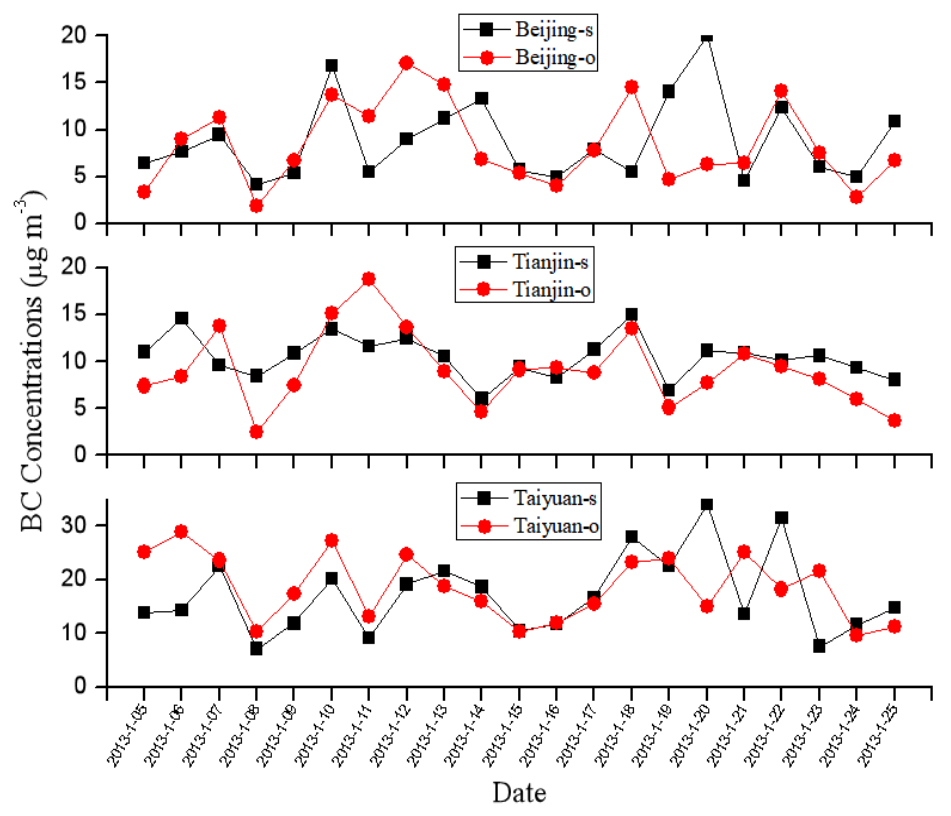

Figure 4. Time series of the observed and simulated black carbon concentrations $\left(\mu \mathrm{g} \cdot \mathrm{m}^{-3}\right)$ in the three major cities (Beijing, Tianjin and Taiyuan) in the North China Plain (NCP).

To better show the model performance, a scatter plot of the simulated and observed BC concentrations is illustrated in Figure 5. The three lines from left to right in the figure are the 2:1, 1:1, and 1:2 ratio lines, respectively, with 269 data points in total. Within the total data points, 228 data points fall inside the 2:1 and 1:2 ratio lines, accounting for $85 \%$ of the total data points. This validation suggests that the WRF-Chem model reasonably captured the spatial and temporal variations of atmospheric black carbon in China, although some discrepancies remain.

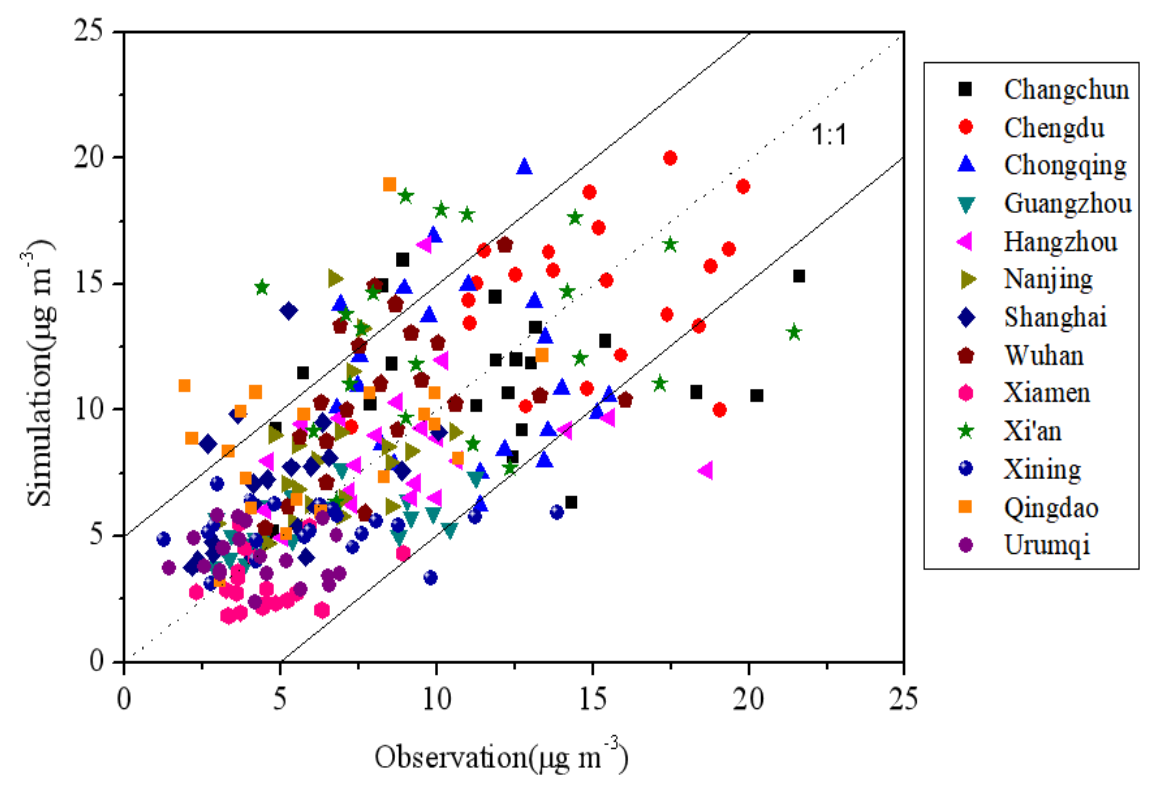

Figure 5. Scatter plot of the simulated and observed BC (black carbon) concentrations in mainland China. 


\subsection{Effect of Diesel Vehicle Emissions on BC}

In order to understand the effect of diesel vehicle emissions on black carbon concentrations in mainland China, the spatial and temporal distributions of black carbon aerosols in 2017 were conducted via two sensitivity studies. One simulation included the total BC emissions, while the second simulation used only the $\mathrm{BC}$ emissions from diesel vehicles. The results are presented as the average over four seasons (January, April, July, and October). Figure 6 shows the annual spatial distributions of black carbon concentrations from all sources of $\mathrm{BC}$ emissions and only diesel vehicle emissions over mainland China, respectively. For all source cases, there were large spatial distributions of $\mathrm{BC}$ concentrations, with the highest value of $6.92 \mu \mathrm{g} \cdot \mathrm{m}^{-3}$ found in the NCP. For only diesel vehicles, the spatial distribution of the $\mathrm{BC}$ concentrations was similar to the total source case but with smaller $\mathrm{BC}$ concentrations. For example, the highest value still occurred in the NCP region, with a regional average value of $1.28 \mu \mathrm{g} \cdot \mathrm{m}^{-3}$, which is five times smaller than the total source case.
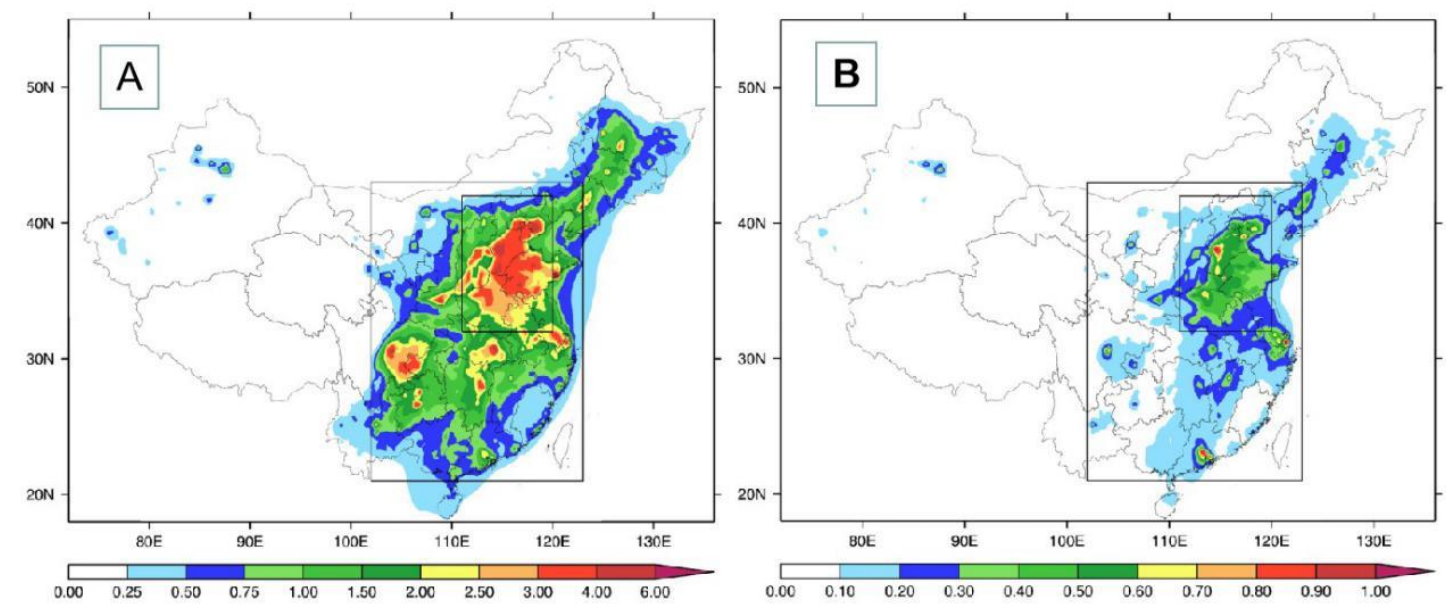

Figure 6. Two different case studies of the annual spatial distributions of black carbon concentrations $\left(\mu \mathrm{g} \cdot \mathrm{m}^{-3}\right)$ over mainland China (A) including all sources and (B) diesel vehicles only. The small rectangle represents the North China Plain, and the large rectangle represents the major urban areas of China.

In addition to the strong spatial distribution of $\mathrm{BC}$ concentrations, there were also significant seasonal variations. As shown in Figure 7A,B, there were different seasonal variations in emissions between the two cases (i.e., all sources and diesel only). For example, the BC concentrations in the NCP were profoundly higher in winter (January) than in other seasons for all sources but this was not for diesel only emissions. The profoundly higher $\mathrm{BC}$ concentrations in the all source case suggest that the other $\mathrm{BC}$ emissions (in addition to the diesel vehicle emissions) play important roles in winter, yielding much higher BC concentrations. For example, the average BC concentration was $4.4 \mu \mathrm{g} \cdot \mathrm{m}^{-3}$ in winter but only $1.2 \mu \mathrm{g} \cdot \mathrm{m}^{-3}$ in summer (July). The ratio between the winter value and the summer value was 3.7. However, in the only diesel vehicle emission case, the seasonal variation was not strong compared to that in the all source case. For example, the average BC concentration was $0.4 \mu \mathrm{g} \cdot \mathrm{m}^{-3}$ in winter but was $0.24 \mu \mathrm{g} \cdot \mathrm{m}^{-3}$ in summer (July). The ratio between the winter value and the summer value was 1.7 .

This result suggests that a reduction in diesel vehicle emissions provides more benefits for reducing $\mathrm{BC}$ pollution not only in winter but also in the other seasons. 

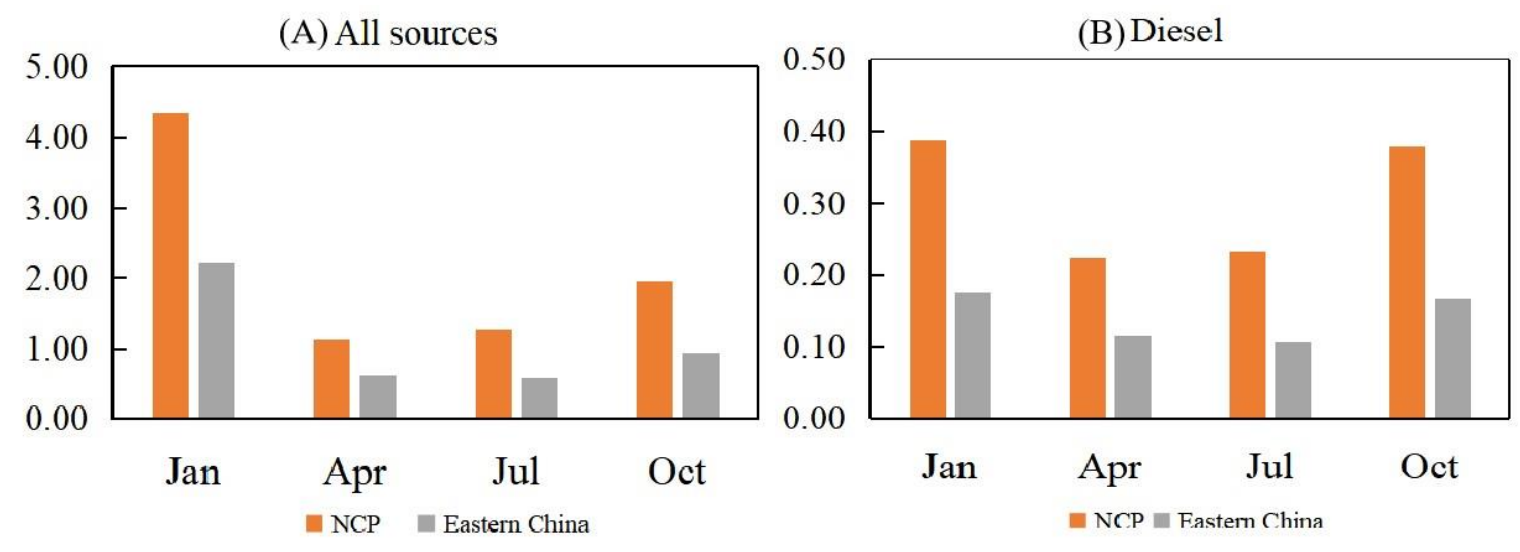

Figure 7. The calculated seasonal variation of the average BC concentrations from all sources (A) and diesel vehicles only (B).

\subsection{Sensitivity Experiments and Potential Benefits of the DPF for BC}

As described in Section 2.3, three sensitivity experiments (CTRL, CASE1, and CASE2) were designed for this study, corresponding to three different diesel vehicle emission scenarios. Figure 8 shows the spatial distributions of the changes in $\mathrm{BC}$ concentrations due to the $\mathrm{BC}$ emission reduction cases (CASE1 and CASE2) versus the base case (CTRL). The results show that when the black carbon emissions from diesel vehicles were reduced by $65 \%$ (CASE1), there was a significant reduction in BC concentrations, especially in the NCP, Shandong province, Yangtze River Delta, Chengdu-Chongqing, and Pearl River Delta regions. The calculated highest black carbon reduction was up to $0.83 \mu \mathrm{g} \cdot \mathrm{m}^{-3}$ in $\mathrm{NCP}$, with an average black carbon reduction of $0.19 \mu \mathrm{g} \cdot \mathrm{m}^{-3}$, accounting for $9.2 \%$ reduction. In eastern China, the average $\mathrm{BC}$ reduction was $0.09 \mu \mathrm{g} \cdot \mathrm{m}^{-3}$, accounting for $9.4 \%$ reduction.

When the black carbon emissions from diesel vehicles were reduced by $39 \%$, the distribution of black carbon reduction (CASE2) was similar to the result of CASE1. However, the magnitude of $\mathrm{BC}$ concentration reduction was smaller than the value of CASE1. The calculated highest black carbon reduction occurred in the NCP, with a reduction of $0.50 \mu \mathrm{g} \cdot \mathrm{m}^{-3}$. The average reduction in $\mathrm{BC}$ concentration in the $\mathrm{NCP}$ was $0.11 \mu \mathrm{g} \cdot \mathrm{m}^{-3}$, accounting for a $5.5 \%$ reduction. In eastern China, this was $0.05 \mu \mathrm{g} \cdot \mathrm{m}^{-3}$, accounting for a $5.6 \%$ reduction.

Table 2 shows the calculated reduction in $\mathrm{BC}$ concentrations averaged in the NCP and eastern China for different cases (CASE1 and CASE 2) in different seasons. In CASE1 (BC emissions from diesel vehicles reduced by $65 \%$ ), the average $\mathrm{BC}$ concentrations decreased by about $\sim 6 \%$ in January and by more than $10 \%$ in the other three seasons. In some regional locations, the highest reductions were greater than $50 \%$ in spring and summer.

In CASE2 (BC emissions from diesel vehicles reduced 39\%), the average BC concentrations decreased by about $\sim 3.5 \%$ in January and by more than $7 \%$ in the other three seasons. Case BC39 presented an average $\sim 3.5 \%$ reduction in January and more than $7 \%$ in the other three seasons for both the NCP and eastern China. In some regional locations, the highest reductions were greater than $30 \%$ in spring and summer.

This study suggests that the installation of DPF in diesel vehicles has a significant effect on atmospheric black carbon concentrations, with $5 \%$ to $10 \%$ BC concentration reductions in polluted areas of China, such as the NCP and eastern China. The reduction in BC was more prominent in spring, summer, and autumn but less effective in winter due to the higher concentrations of pollutants in the atmosphere.

DPF have been used for years in all road diesel engines worldwide. Most previous studies have focused on the direct emissions from DPF-equipped diesel engines, especially nonvolatile particle emissions, such as black carbon or soot [33-35]. Previous studies show that heavy-duty engines equipped with DPF emit two orders of magnitude less mass of total particles [36] and average BC emission factors decrease by $76 \pm 22 \%$ [34] when compared to the case without DPF. However, there are 
few model simulation assessments of atmospheric black carbon concentration reduction by diesel trucks equipped with DPF. This study used WRF-Chem, a state-of-the-art model to simulate particle diffusion, distribution and chemical reactions in the atmosphere due to the use of DPF on diesel vehicles. The results indicate that the usage of DPF in diesel vehicles produce important benefits with respect to atmospheric air quality and should be promoted, especially in geographical areas suffering from poor air quality.
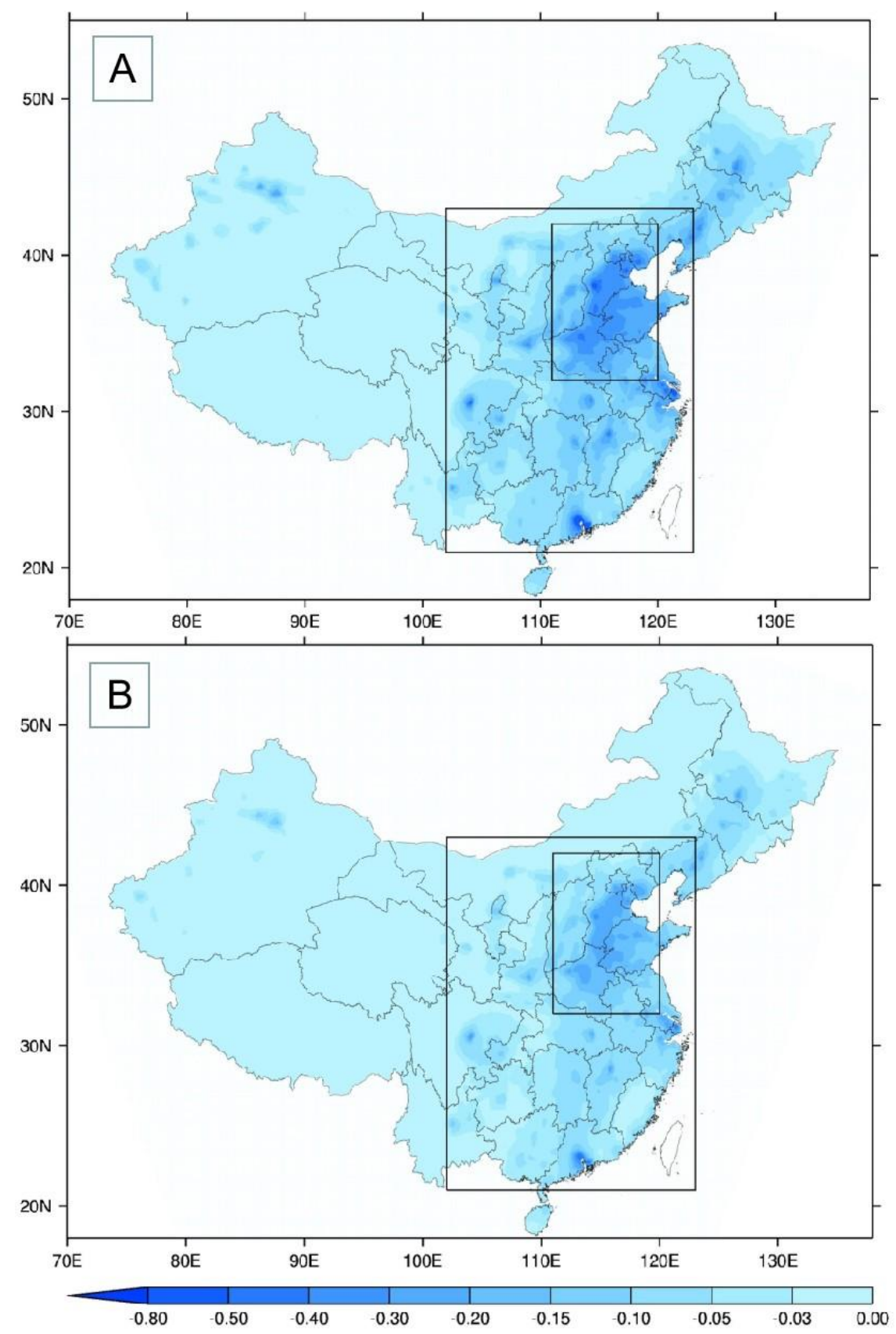

Figure 8. The spatial distribution of changes in black carbon concentrations $\left(\mu \mathrm{g} \cdot \mathrm{m}^{-3}\right)$ for the two different emission reduction scenarios (CASE1 and CASE2) versus the base case CTRL(A), CASE1 versus CTRL; (B), CASE 2 versus CTRL). The small rectangle represents the North China Plain (NCP), and the big rectangle represents the region of eastern China (the most major urban areas of China). 
Table 2. The changes in BC concentrations were averaged in the NCP and eastern China due to the BC emission reduction cases (CASE1 and CASE2) versus the base case (CTRL) in different seasons.

\begin{tabular}{cccccccc}
\hline \multirow{2}{*}{ Seasons } & \multirow{2}{*}{ Areas } & \multicolumn{2}{c}{ CASE1 (65\% Reduction) } & \multicolumn{3}{c}{ CASE2 (39\% Reduction) } \\
\cline { 3 - 7 } & & High & Low & Mean & High & Low & Mean \\
\hline \multirow{2}{*}{ Jan } & NCP & $9.6 \%$ & $3.1 \%$ & $5.9 \%$ & $5.8 \%$ & $1.9 \%$ & $3.5 \%$ \\
& Eastern China & $25.5 \%$ & $1.0 \%$ & $6.2 \%$ & $15.3 \%$ & $0.6 \%$ & $3.7 \%$ \\
\multirow{2}{*}{ Apr } & NCP & $17.2 \%$ & $6.7 \%$ & $12.7 \%$ & $10.3 \%$ & $4.0 \%$ & $7.6 \%$ \\
& Eastern China & $52.2 \%$ & $3.6 \%$ & $12.8 \%$ & $31.3 \%$ & $2.2 \%$ & $7.7 \%$ \\
\multirow{2}{*}{ Jul } & NCP & $17.2 \%$ & $5.7 \%$ & $11.9 \%$ & $10.3 \%$ & $3.4 \%$ & $7.2 \%$ \\
& Eastern China & $52.1 \%$ & $3.3 \%$ & $12.8 \%$ & $31.2 \%$ & $2.0 \%$ & $7.7 \%$ \\
& NCP & $17.8 \%$ & $6.3 \%$ & $12.6 \%$ & $10.7 \%$ & $3.8 \%$ & $7.6 \%$ \\
& Eastern China & $42.7 \%$ & $3.1 \%$ & $11.9 \%$ & $25.6 \%$ & $1.9 \%$ & $7.2 \%$ \\
\hline
\end{tabular}

\section{Summary}

Black carbon (BC) particles have an important effect on the climate and the environment. The main sources of $\mathrm{BC}$ emissions include industrial activities, vehicles, biomass burning, and residential burning. Mobile sources account for $\sim 25 \%$ of BC emissions, among which $\sim 70 \%$ belong to diesel fuel combustion. The rapid growth of diesel vehicles in China in recent years has resulted in great attention being focused on the control of pollution due to fine particles. As a mature vehicle exhaust control technology, DPF can be used to reduce the black carbon emissions of diesel vehicles and is potentially a suitable pollution control method for a large number of existing high-polluting diesel vehicles in China. However, despite the high purification efficiency of DPF in laboratory and small-scale experiments, its emission reduction efficiency and effects on air quality have not been investigated on a national scale and are not well understood. In this study, the potential reduction in atmospheric black carbon and benefits induced by using DPF in diesel vehicles in mainland China were evaluated using the WRF-Chem model. The black carbon emissions of diesel vehicles were first estimated based on the emission inventory supported by Tsinghua University (Zhang et al., 2009) and updated by the "China Vehicle Environmental Management Annual Report". Using the WRF-Chem model, three sensitivity experiments (CTRL, CASE1, and CASE2) were designed for different black carbon emission reduction scenarios with different DPF applications. The model sensitivity studies focused on the scope of potential benefits through reduction BC pollution in China when adopting DPF control technology. The main results are summarized as follows:

1. Although China implemented stringent emission standards and accelerated the elimination of yellow-label vehicles from 2013 to 2017, the reduction in particulate matter from diesel vehicles was not clearly improved. The annual black carbon emissions of diesel vehicles in 2013 and 2017 were respectively $313,300 \mathrm{~T}$ and $269,751 \mathrm{~T} \mathrm{y}^{-1}$, corresponding to 19.11 and 19.57 million diesel vehicles.

2. Both simulated black carbon from all sources and diesel vehicles in 2017 exhibited specific characteristics in terms of spatial distribution, in which higher BC concentrations are mainly concentrated in densely populated areas. The highest $\mathrm{BC}$ concentrations occurred in the large cities of the North China Plain (NCP). For example, in three large NCP cities (Beijing, Tianjin, and Taiyuan), the average observed and simulated black carbon concentrations in 2017 were respectively 8.4 and $8.6 \mu \mathrm{g} \cdot \mathrm{m}^{-3}$ in Beijing, 9.1 and $10.5 \mu \mathrm{g} \cdot \mathrm{m}^{-3}$ in Tianjin, and 18.6 and $17.0 \mu \mathrm{g} \cdot \mathrm{m}^{-3}$ in Taiyuan.

3. There are also important seasonal variations of $\mathrm{BC}$ concentrations in the NCP. For example, in 2017, the average BC concentration in the NCP was $0.4 \mu \mathrm{g} \cdot \mathrm{m}^{-3}$ in winter but $0.24 \mu \mathrm{g} \cdot \mathrm{m}^{-3}$ in summer (July). The ratio between the values for winter and summer was 1.7. However, the BC concentrations in the NCP were profoundly higher in winter than in summer, with a ratio of 3.7. This result suggests that a reduction in diesel vehicle emissions has more benefits for reducing $B C$ pollution not only in winter but also in other seasons. 
4. The sensitivity studies show that in CASE1 (BC emissions from diesel vehicles reduced by $65 \%$ ), the average $\mathrm{BC}$ concentrations decreased by about $~ 6 \%$ in January and by more than $10 \%$ in other seasons. In some regional locations, the highest reductions were greater than $50 \%$. In CASE2 (BC emissions from diesel vehicles reduced by $39 \%$ ), the average BC concentrations decreased by about $3.5 \%$ in January and by more than $7 \%$ in other seasons.

This study shows that installing a DPF to control black carbon emissions and reduce the subsequent environmental and climatic impact has a significant and positive effect. Thus, the use of DPF can be considered as an executable control measure for diesel vehicle emission reduction.

Author Contributions: Conceptualization, X.T.; data curation, J.Z. and S.Z.; formal analysis, J.Z. and S.Z.; funding acquisition, X.T.; methodology, X.T., S.Z. and G.L.; project administration, X.T.; resources, S.L., T.Z. and W.D.; software, J.Z., Y.Y. and G.L.; supervision, X.T. and G.L.; validation, J.Z., S.L., T.Z. and W.D.; visualization, S.L., T.Z. and W.D.; writing — original draft, J.Z.; writing—review and editing, X.T. and Y.Y. All authors have read and agreed to the published version of the manuscript.

Funding: This work was funded by the National Natural Science Foundation of China (NSFC) under Grant Nos. 41430424 and 41730108.

Acknowledgments: The authors thank the supports from the Center for Excellence in Urban Atmospheric Environment, Institute of Urban Environment, Chinese Academy of Sciences.

Conflicts of Interest: The authors declare that they have no known competing financial interests or personal relationships that could have influenced the work reported in this paper.

\section{References}

1. Bond, T.C.; Doherty, S.J.; Fahey, D.W.; Forster, P.M.; Berntsen, T.; DeAngelo, B.J.; Flanner, M.G.; Ghan, S.; Kärcher, B.; Koch, D.; et al. Bounding the role of black carbon in the climate system: A scientific assessment. J. Geophys. Res. Atmos. 2013, 118, 5380-5552. [CrossRef]

2. Andreae, M.O.; Gelencsér, A. Black carbon or brown carbon: The nature of light-absorbing carbonaceous aerosols. Atmos. Chem. Phys. 2006, 6, 3131-3148. [CrossRef]

3. Samset, B.H.; Myhre, G.; Herber, A.; Kondo, Y.; Li, S.-M.; Moteki, N.; Koike, M.; Oshima, N.; Schwarz, J.P.; Balkanski, Y.; et al. Modelled black carbon radiative forcing and atmospheric lifetime in AeroCom Phase II constrained by aircraft observations. Atmos. Chem. Phys. 2014, 14, 12465-12477. [CrossRef]

4. Bond, T.C.; Streets, D.G.; Yarber, K.F.; Nelson, S.M.; Woo, J.-H.; Klimont, Z. A technology-based global inventory of black and organic carbon emissions from combustion. J. Geophys. Res. 2004, 109, D14203. [CrossRef]

5. Bond, T.C.; Bhardwaj, E.; Dong, R.; Jogani, R.; Jung, S.; Roden, C.; Streets, D.G.; Trautmann, N.M. Historical emissions of black and organic carbon aerosol from energy-related combustion, 1850-2000. Glob. Biogeochem. Cycles 2007, 21. [CrossRef]

6. Jacobson, M.Z. Investigating cloud absorption effects: Global absorption properties of black carbon, tar balls, and soil dust in clouds and aerosols. J. Geophys. Res. 2012, 117. [CrossRef]

7. Apte, J.S.; Brauer, M.; Cohen, A.J.; Ezzati, M.; Pope, C.A. Ambient PM 2.5 Reduces Global and Regional Life Expectancy. Environ. Sci. Technol. Lett. 2018, 5, 546-551. [CrossRef]

8. Yang, H.-H.; Arafath, S.M.; Lee, K.-T.; Hsieh, Y.-S.; Han, Y.-T. Chemical characteristics of filterable and condensable PM 2.5 emissions from industrial boilers with five different fuels. Fuel 2018, 232, 415-422. [CrossRef]

9. Ying, Y.; Liu, D. Effects of Flame Configuration and Soot Aging on Soot Nanostructure and Reactivity in n-Butanol-Doped Ethylene Diffusion Flames. Energy Fuels 2018, 32, 607-624. [CrossRef]

10. Soltani, S.; Andersson, R.; Andersson, B. The effect of exhaust gas composition on the kinetics of soot oxidation and diesel particulate filter regeneration. Fuel 2018, 220, 453-463. [CrossRef]

11. Grell, G.A.; Peckham, S.E.; Schmitz, R.; McKeen, S.A.; Frost, G.; Skamarock, W.C.; Eder, B. Fully coupled "online" chemistry within the WRF model. Atmos. Environ. 2005, 39, 6957-6975. [CrossRef]

12. Tie, X.X.; Madronich, S.; Li, G.; Ying, Z.; Zhang, R.; Garcia, A.; Taylor, J.; Liu, Y. Characterizations of chemical oxidants in Meixo City: A regional chemical dynamical model (WRF-Chem) study. Atmos. Environ. 2007, 41, 1989-2008. [CrossRef] 
13. Tie, X.; Madronich, S.; Li, G.; Ying, Z.; Weinheimer, A.; Apel, E.; Campos, T. Simulation of Mexico City plumes during the MIRAGE-Mex field campaign using the WRF-Chem model. Atmos. Chem. Phys. 2009, 9, 4621-4638. [CrossRef]

14. Li, G.; Bei, N.; Tie, X.; Molina, L.T. Aerosol effects on the photochemistry in Mexico City during MCMA-2006/MILAGRO campaign. Atmos. Chem. Phys. 2011, 11, 5169-5182. [CrossRef]

15. Stockwell, W.R.; Middleton, P.; Chang, J.S.; Tang, X. The second generation regional acid deposition model chemical mechanism for regional air quality modeling. J. Geophys. Res. 1990, 95, 16343-16367. [CrossRef]

16. Ackermann, I.J.; Hass, H.; Memmesheimer, M.; Ebel, A.; Binkowski, F.S.; Shankar, U. Modal aerosol dynamics model for Europe. Atmos. Environ. 1998, 32, 2981-2999. [CrossRef]

17. Schell, B.; Ackermann, I.J.; Hass, H.; Binkowski, F.S.; Ebel, A. Modeling the formation of secondary organic aerosol within a comprehensive air quality model system. J. Geophys. Res. 2001, 106, 28275-28293. [CrossRef]

18. Iacono, M.J.; Delamere, J.S.; Mlawer, E.J.; Shephard, M.W.; Clough, S.A.; Collins, W.D. Radiative forcing by long-lived greenhouse gases: Calculations with the AER radiative transfer models. J. Geophys. Res. $2008,113$. [CrossRef]

19. Morrison, H.; Thompson, G.; Tatarskii, V. Impact of Cloud Microphysics on the Development of Trailing Stratiform Precipitation in a Simulated Squall Line: Comparison of One- and Two-Moment Schemes. Mon. Weather Rev. 2009, 137, 991-1007. [CrossRef]

20. Emmons, L.K.; Walters, S.; Hess, P.G.; Lamarque, J.-F.; Pfister, G.G.; Fillmore, D.; Granier, C.; Guenther, A.; Kinnison, D.; Laepple, T.; et al. Description and evaluation of the Model for Ozone and Related chemical Tracers, version 4 (MOZART-4). Geosci. Model Dev. 2010, 3, 43-67. [CrossRef]

21. Chen, F.; Dudhia, J. Coupling an advanced land surface-hydrology model with the Penn state-NCAR MM5 modeling system. Part I: Model implementation and sensitivity. Mon. Weather Rev. 2001, 129, 569-585. [CrossRef]

22. Hong, S.-Y.; Noh, Y.; Dudhia, J. A New Vertical Diffusion Package with an Explicit Treatment of Entrainment Processes. Mon. Weather Rev. 2006, 134, 2318-2341. [CrossRef]

23. Grell, G.A.; Dévényi, D.A. Generalized approach to parameterizing convection combining ensemble and data assimilation techniques. Geophys. Res. Lett. 2002, 29, 31-38. [CrossRef]

24. Zhang, Q.; Streets, D.G.; Carmichael, G.R.; He, K.B.; Huo, H.; Kannari, A.; Klimont, Z.; Park, I.S.; Reddy, S.; Fu, J.S.; et al. Asian emissions in 2006 for the NASA INTEX-B mission. Atmos. Chem. Phys. 2009, 9, 5131-5153. [CrossRef]

25. Li, M.; Zhang, Q.; Kurokawa, J.-I.; Woo, J.-H.; He, K.; Lu, Z.; Ohara, T.; Song, Y.; Streets, D.G.; Carmichael, G.R.; et al. MIX: A mosaic Asian anthropogenic emission inventory under the international collaboration framework of the MICS-Asia and HTAP. Atmos. Chem. Phys. 2017, 17, 935-963. [CrossRef]

26. Zheng, B.; Huo, H.; Zhang, Q.; Yao, Z.L.; Wang, X.T.; Yang, X.F.; Liu, H.; He, K.B. High-resolution mapping of vehicle emissions in China in 2008. Atmos. Chem. Phys. 2014, 14, 9787-9805. [CrossRef]

27. Wang, Y.J.; Ji, Z.; Yin, H.; Huang, Z.H.; Ma, D.; Wang, H.L.; Qian, L.Y.; Xie, Q.; Xiao, H. Analysis of black carbon emissions from diesel vehicles in China from 2010-2013. Environ. Dev. Sustain. 2015, 40, 19-21.

28. Chow, J.C.; Watson, J.G.; Pritchett, L.C.; Pierson, W.R.; Frazier, C.A.; Purcell, R.G. The dri thermal/optical reflectance carbon analysis system: Description, evaluation and applications in U.S. Air quality studies. Atmos. Environ. Part A. Gen. Top. 1993, 27, 1185-1201. [CrossRef]

29. Chow, J.C.; Watson, J.G.; Chen, L.W.A.; Arnott, W.P.; Moosmüller, H.; Fung, K. Equivalence of elemental carbon by thermal/optical reflectance and transmittance with different temperature protocols. Environ. Sci. Technol. 2004, 38, 4414-4422. [CrossRef]

30. Cao, J.J.; Lee, S.C.; Ho, K.F.; Zhang, X.Y.; Zou, S.C.; Fung, K.; Chow, J.C.; Watson, J.G. Characteristics of carbonaceous aerosol in Pearl River Delta Region, China during 2001 winter period. Atmos. Environ. 2003, 37, 1451-1460. [CrossRef]

31. Cao, J.J.; Shen, Z.X.; Chow, J.C.; Watson, J.G.; Lee, S.C.; Tie, X.X.; Ho, K.F.; Wang, G.H.; Han, Y.M. Winter and Summer $\mathrm{PM}_{2.5}$ Chemical Compositions in Fourteen Chinese Cities. J. Air Waste Manag. Assoc. 2012, 62, 1214-1226. [CrossRef] [PubMed]

32. Li, R.; Han, Y.; Wang, L.; Shang, Y.; Chen, Y.J. Differences in oxidative potential of black carbon from three combustion emission sources in China. J. Environ. Manag. 2019, 240, 57-65. [CrossRef] [PubMed] 
33. Bishop, G.A.; Hottor-Raguindin, R.; Stedman, D.H.; McClintock, P.; Theobald, E.; Johnson, J.D.; Lee, D.-W.; Zietsman, J.; Misra, C. On-Road Heavy-Duty Vehicle Emissions Monitoring System. Environ. Sci. Technol. 2015, 49, 1639-1645. [CrossRef]

34. Preble, C.V.; Dallmann, T.R.; Kreisberg, N.M.; Hering, S.V.; Harley, R.A.; Kirchstetter, T.W. Effects of Particle Filters and Selective Catalytic Reduction on Heavy-Duty Diesel Drayage Truck Emissions at the Port of Oakland. Environ. Sci. Technol. 2015, 49, 8864-8871. [CrossRef]

35. Karjalainen, P.; Rönkkö, T.; Simonen, P.; Ntziachristos, L.; Juuti, P.; Timonen, H.; Teinilä, K.; Saarikoski, S.; Saveljeff, H.; Lauren, M.; et al. Strategies to Diminish the Emissions of Particles and Secondary Aerosol Formation from Diesel Engines. Environ. Sci. Technol. 2019, 53, 10408-10416. [CrossRef] [PubMed]

36. Khalek, I.A.; Blanks, M.G.; Merritt, P.M.; Zielinska, B. Regulated and Unregulated Emissions from Modern 2010 Emissions-Compliant Heavy-Duty on-Highway Diesel Engines. J. Air Waste Manag. Assoc. 2015, 65, 987-1001. [CrossRef] [PubMed]

(C) 2020 by the authors. Licensee MDPI, Basel, Switzerland. This article is an open access article distributed under the terms and conditions of the Creative Commons Attribution (CC BY) license (http://creativecommons.org/licenses/by/4.0/). 